\title{
Will ban provoke challenge?
}

\section{Washington}

THE board of directors of the Parkinson's Disease Foundation (PDF) will decide on 11 September whether or not to sue the US administration over its ban on the use of federal funds to support fetäl tissue transplantation research.

But although patients with Parkinson's disease are one of the main groups that could potentially benefit from a lifting of the moratorium, Dinah Orr, PDF executive director, says, "we will not want to take the whole thing on our own shoulders". So far, the United Parkinson Foundation and the Association of American Medical Colleges (AAMC), which represents medical schools, teaching hospitals and academic societies, are also considering whether to support the legal challenge.

A temporary ban on research involving the transplantation of human fetal tissue derived from induced abortions into human recipients was introduced in March 1988 by the then Assistant Secretary of Health Robert Windom. It was precipitated by a request by scientists at the National Institutes of Health (NIH) to carry out an experiment involving the transplantation of human fetal cells into the brain of a patient with Parkinson's disease. Windom withheld approval, but convened an NIH panel of ethical, legal

\section{BRAZILIAN SPACE PROGRAMME \\ Iraqi link threatens \\ progress \\ São Paulo}

BRAZIL's space programme is one of the victims of the crisis in the Middle East triggered by Iraq's invasion of Kuwait - or so at least the Brazilian Air Force believes. The air force has responsibility for the development of Brazil's Satellite Launcher Vehicle and claims that the United States will not return parts of the rocket sent for thermal treatment because of Brazil's military links with Iraq.

In the past, Brazil has sold much military equipment to Iraq, including rockets developed from scientific sounding rockets. It also has experts in Iraq helping with a programme to develop an air-to-air missile, the Piranha, which is similar to the US Sidewinder missile.

The United States has long been suspicious that the satellite launch vehicle might be converted into a long-range missile, and is concerned that the project is managed by the Brazilian Air Force rather than a civilian agency. But no immediate military application is possible as the rocket is not expected to be ready until 1994 — five years behind the original schedule.

Ricardo Bonalume and scientific experts to examine the issues relating to human fetal tissue transplantation research.

Although the panel concluded that such research should be permitted and the ban on federal funding lifted, Health and Human Services (HHS) Secretary Louis Sullivan rejected the advice and extended the ban indefinitely in November 1989 (see Nature 342, 105; 1989).

An attempt by Representative Henry Waxman (Democrat, California) to overturn the ban by legislative means will have an uphill struggle when his bill is considered by the health and environment subcommittee in early September (see Nature 346, 598; 16 August 1990).

David Moore, assistant director in the Office of Government Relations at the AAMC, says his organization supports Waxman's initiative, but believes that the chances of the legislation passing this term "are pretty remote", which is why AAMC is keeping all its "options open". The AAMC's executive council meets at the end of September to consider whether or not to support action to challenge the ban in the federal court, by which time, Moore says, they should have a better idea "whether or not the legislation is going to go forward".

A legal study by the law firm of Fulbright and Jaworski, commissioned by AAMC, states that "the merits of a lawsuit challenging the moratorium appear strong" and could proceed on two fronts. First, the HHS failed to comply with the Administrative Procedure Act, which requires both public notice and an opportunity for public comment before a rule is established. Second, the study says that the Secretary's action appears to be "arbitrary and capricious", in that the only rationale given for extending the ban indefinitely was that it might cause an increase in the number of abortions.

"Instead of making it a factor to consider in weighing whether it was appropriate to fund the research, he [the Secretary] made it the determining factor - the only factor", says attorney Stephen McNabb who helped prepare the study.

Michael Astrue, General Counsel for the Public Health Service (PHS), is unconcerned by the prospect of a lawsuit and argues that the PHS statute "clearly commits discretion to the Secretary to either engage in this research or not". By making the ban indefinite and not permanent, Astrue says "the Secretary wanted to indicate that he would continue to have an open mind on the issue", particularly as the abortion law is in a state of flux and because technology in this area changes very rapidly.

Even if the Parkinson's disease organizations and AAMC decide to go ahead,
More (students) means more (pain)

\section{London}

BRITISH higher education will become "a demoralized, poor quality system" unless there are increased funds for teaching to support the government's planned expansion of student numbers, warn university vice-chancellors and polytechnic directors. But a large increase from public funds is unlikely, whatever the political colour of the next government, so increased costs may have to be borne by students.

A report from a working group set up by the Committee of Vice-Chancellors and Principals and the Committee of Directors of Polytechnics (the first occasion universities and polytechnics have acted together in this way) suggests a number of financial mechanisms, all involving increased payments by students. One possibility is for students to borrow money to meet some of their teaching costs, similar to the controversial 'top-up' loans scheme under which, starting this academic year, students will over the next few years borrow to cover an increasing proportion of their living expenses. Other suggestions include the introduction of a 'graduate tax' and charging teaching costs in full directly to students, with government support provided by a system of scholarships. Working group chairman Professor John Ashworth, from the University of Salford, says that the report's primary importance is not to produce a detailed funding mechanism, but rather to combat the government's current 'wait and see' policy on the finances of higher education. "A decision will have to be made this year", he says.

In the run-up to a general election, further upheaval of higher education may not be a government priority. But the costs of teaching extra students are expected to produce a crisis in 1991-92. Under the new competitive bidding system for student places, universities have asked for a 19 per cent increase in students over the four years to 1994-95. But most universities have bid for places at, or only just below, the Universities Funding Council's suggested maximum guide prices (see Nature, 345, 468 ; 7 June 1990), subverting the government's plan to realize 'economies of scale', increasing student numbers at a lower average cost.

Peter Aldhous

important issues remain. They will need to muster support from other disease groups to meet the legal costs, and will have to decide and which of them, from a tactical point of view, should take the lead. As Lawrence Hoffheimer, attorney with Noto, Oswald, Hoffheimer, Eisman and Miller, puts it, "who has standing [the legal term for the right of a plaintiff to raise the claim] and who pays for the suit are two different matters" 